\title{
Cervantes en Lope: la aventura de la escritura de las Novelas a Marcia Leonarda a La
}

\section{Dorotea}

Cervantes and Lope: the Adventure of Writing from Novelas a Marcia Leonarda to La Dorotea

\section{Carlos Brito Diaz}

Universidad de La Laguna, España

\section{RESUMEN:}

El siguiente trabajo plantea un recorrido por diversas obras de Lope de Vega desde La Filomena hasta La Dorotea desde un eje que da cuenta de la presencia de Lope dentro de sus obras ya no desde la crítica biografista. Así a lo largo de estas páginas se justificarán los modos de autoconstrucción del poeta como un escritor que indaga con profundidad estética y epistemológica en una retórica del libro y de la letra escrita, que especula acerca del texto como patrimonio de propiedad intelectual, como representación del mundo y como símbolo de la praxis propia y ajena así como construye su materia poética y narrativa desde el nivel metaliterario. Se analizará en estas obras posteriores a 1620 los mecanismos a partir de los que Lope poetiza al propio Lope que escribe, al mismo Lope que se lee y se comenta a sí mismo como el agente en el principio del acto creador, en el puro acto de la escritura del mundo que escribe y que lo escribe.

Palabras Clave: Lope de Vega, Metatextualidad, Poética, Barroco español.

\section{ABSTRACT:}

This article focuses different Lope de Vega's works published after 1620 from La Filomena to La Dorotea in order to describe the author in them, as a writer who investigates, an intellectual who speculates and as a reader who comments himself. In this way this paper analyzes how Lope is the agent of a creative act: the act of writing a world that writes and writes him.

KEYWORDS: Lope de Vega, La Dorotea, Elegiac gender, Parody.

El viejo poeta en su invierno literario (y vital) escribía (Lope de Vega, 2008:173):

—Pluma, las Musas de mi ingenio autoras,
versos me piden hoy. iAlto a escribillos!
Yo solo escribiré, señor Burguillos,
éstas que me dictó rimas sonoras.
— ¿A Góngora me acota en tales horas?
arrímese dos Musas cantimploras.
Dejemos la campaña, el monte, el valle,
y alabemos señores. —No le entiendo,
¿morir quiere de hambre? - Escriba y calle.
A mi ganso me vuelvo en prosiguiendo,
que es desdicha después de no premialle
nacer volando y acabar mintiendo.

El coloquio del escritor con la pluma, lugar común asentado en la tradición poética española al menos desde el Diálogo del autor con su péñola de Cristóbal de Castillejo de 1550, conjura en el Fénix una riquísima veta conceptual y retórica que reformula una poética de la escritura y una constante especulación sobre el acto de componer, aquí derivadas hacia el espejo cóncavo o convexo de la parodia: la burla del gongorismo o la inevitable sumisión a los señores no son prédicas del desengaño sino apostillas metatextuales de la letra 
transformada en juego ontológico; como en las Etimologías de san Isidoro, según anota Curtius (1984, I:439), la pluma con la hendidura que tiene en el extremo representa una unidad resuelta en dualismo, aquí símbolo de la escisión autorial de Lope y su heterónimo, el maestro Burguillos. Aparte de Shakespeare es difícil encontrar en el Siglo de Oro un escritor que indague con profundidad estética y epistemológica en una retórica del libro y de la letra escrita con el refinamiento de Lope: no hacemos referencia únicamente al alarde estilístico de su pródiga veta metafórica, sino a la omnipresente especulación del texto como patrimonio de propiedad intelectual, como representación del mundo y como símbolo de la praxis propia y ajena al modo de una suerte de ontología desatada en la metaescritura. Lope poetiza, como acabamos de ver, al propio Lope que escribe, al mismo Lope que se lee y se comenta a sí mismo (y a los otros), no ya como el escrilector de alardes metafictivos en las Novelas a Marcia Leonarda, sino como el agente en el principio del acto creador, como el sacerdote-escriba - al modo de Borges - en el puro acto de la escritura del mundo que escribe y que lo escribe. A partir del ciclo de madurez correspondiente a la década de 1620 (sabemos que el Fénix tuvo varios), en Lope se afianza y se consolida, un modo, una maniera, un estilo (tomado en metonimia etimológica, esto es, como 'pluma o cálamo' también) y una dirección metatextuales que decantan una escritura en seso con la soltura conceptual y omnisciente de Cervantes, si bien no siempre con el sabor especulativo de éste. Y esta progresión reflexiva hacia el centro del texto y de la creación literaria es casi una pauta en la que desembocan otros autores del Barroco en sus ciclos de madurez: es el Góngora de las Soledades y su texto del mundo, como ha estudiado Sánchez Robayna (1993), el Calderón de los últimos autos sacramentales donde se ha advertido la tendencia a lo teleológico y, por supuesto, el Cervantes del Persiles, de la Segunda Parte del Quijote ("Para mí sola nació don Quijote, y yo para él; él supo obrar y yo escribir; solos los dos somos para en uno”, [II, 74]) y del Viaje del Parnaso ("Pues veis que no me han dado algún soneto/ que ilustre deste libro la portada,/ venid vos, pluma mía mal cortada,/ y hacedle, aunque carezca de discreto" [Preliminares]), donde encontramos, no de forma casual, el mismo juego (auto)fictivo del escritor en plática con su pluma e, inducido por el episodio Avellaneda, una temprana postulación de los derechos de autor y de la propiedad intelectual.

Los múltiples empleos de lo escriturario en la poesía y en la prosa de Lope (al margen de su producción dramática, donde menudean en fértil cornucopia) nos acercan al escribidor que se contempla en la imagen que proyecta de sí mismo en el instante en que escribe, por tanto una autoimagen, reveladora de que el mundo es escritura(“:Que no escriba, decís, o que no viva?”) y de que la escritura es el mundo tomado al pie de la letra (Egido, 1995). Al margen del viejo tópico del Liber Mundi, que en el Fénix cristaliza en exquisitas imágenes, descubrimos en el Lope último una progresiva textualización de la escritura como ejercicio especular de una omnisciencia crítica de la tradición y de sí a la maniera cervantina, concertando las graves disquisiciones sobre el escritor, la escritura y el lector con el donaire burlesco de la (auto)parodia de géneros e influjos contemporáneos, actitud que desemboca en la intensidad metalibresca de La Dorotea, homenaje y burla de la literatura de su tiempo, donde la hibridez celestinesca se sazona con un audaz cervantinismo. ${ }^{3}$

Desde la Arcadia (1598), ese temprano ejercicio de madurez, el Fénix aporta un discurso engastado en la veta más sinestésica entre arte y literatura que desplaza el interés de la convencional retórica bucólica a un relato paralelo en forma de comento o apostilla merced a una oportuna fórmula renacentista que le proporcionaba el género pastoril: la academia de árcades en cuyo seno se acogen debates, certámenes y digresiones convocaba la atmósfera literaturizada de una oficina o poliantea (Brito Díaz, 1998) que Lope tanto consultó, sobre misceláneos saberes donde confluyen la filosofía hermética, la magia, la cultura jeroglífica, las gallerie artísticas, el universo de los emblemas y de las empresas o el programa de las artes liberales en enciclopédico fluir. El viaje existencial del pastor-vate hacia el paradigma del doctus poeta venerado en la Antigüedad se cifra aquí merced a un periplo alegórico que oscila del "Jardín de Venus" al "Museo del Discreto", trazando un peregrinaje gracianesco — según se ha advertido- que trasmuta el humor amoroso en furor poético: una vez atemperados la memoria, la voluntad y el entendimiento, Anfriso está preparado para acceder a las estancias iluminadoras del Templo del Desengaño. Estos pastores librescos o literarios conforman un cenáculo platónico cuyas pláticas eruditas enlazan con la filiación filosófica y artística 
del relato pastoril en relación con lo académico como convergencia de saberes. Con sabor e intención bien diferentes, en La Dorotea otro concilio de eruditos anota y comenta un soneto culterano, desnudando en espejo cóncavo a poetas y críticos, con el que se cierra un ciclo simbólico de literaturización de los ejercicios de academias y tertulias en ocasiones en el entorno del encomio paradójico (Brito Díaz, 2010; véanse también los trabajos de Núñez Rivera, 1997, 1998 y su edición de Mosquera de Figueroa, 2010). Con sus primeras obras ambiciosas (La Arcadia, el Isidro, La Dragontea y, unos años después, La hermosura de Angélica), el Fénix había intentado fraguarse la credencial de autor serio y docto y dejar de ser contemplado únicamente como el aplaudido escritor de comedias: en su edición de La Dragontea, Sánchez Jiménez (2007: 16) ha demostrado la preocupación de Lope por el trabajo de documentación y de archivo. Al finalizar el siglo y huyendo de la etiqueta de escritor popular y fácil, Lope elige, tras garantizarse la unanimidad en la escena, las formas elevadas de la poesía épica y de la ficción bucólica: en las primeras la erudición procede de la asistencia de fuentes históricas; en la segunda de la sapiencia que despliegan sus personajes con el concurso de las aderezadas digresiones que estorban la fábula y que adelantan a los "intercolunios" de las novellas lopescas, una nueva circularidad metaliteraria del autor consigo mismo. Según advertimos en su día (1998:57), La Arcadia destila el ejercicio enciclopédico del ameno convivio que concitaba el espíritu humanista por donde

desfilarán fábulas, experiencias sobrenaturales, prácticas de hechicería, lides emblemáticas, juegos zodiacales, ejercicios de magia y una silva de varia lección sobre agricultura, botánica, ciencias ocultas, zoología, historia, cosmografía, mitología, filosofía amorosa, astrología y humanidades...

Estos sujetos se conjugarán con el saber hermético o con el simbolismo alegórico de bestiarios y lapidarios o con debates sobre el parangón entre poesía y pintura que estallará en la siguiente centuria con la defensa de la liberalidad o dignidad de los oficios mecánicos, entre los que se hallaban bordadores, herreros y pintores, y con el célebre pleito contra la Hacienda de su Majestad, en el que participaron el propio Lope, Jáuregui o Calderón en defensa de los profesores de dibujo — según han estudiado Francisco Calvo Serraller (1991), Javier Portús Pérez (1999) y Antonio Sánchez Jiménez (2011), entre otros-y cuyo eco se inicia oficialmente con la Noticia general para la estimación de las artes de Gaspar Gutiérrez de los Ríos en 1600 y desemboca en la obra de Velázquez: Las Meninas, según ha apuntado Santiago Sebastián (1995: 232-249), pueden interpretarse como cómplices de un programa iconológico que reivindica la dignidad del arte de la pintura y, por cierto, con estrategias igualmente cervantinas: el pintor en la pintura, el proceso de composición en la obra, el espectador en el plano de representación, el cuadro en el cuadro (como trasposición de la técnica de la pittura nella pittura). En la novela pastoril de Lope la discusión y la controversia vienen de la mano de la escritura de las artes donde la letra anota a la piedra, al lienzo, a la imagen o al túmulo; los mismos personajes intervienen el relato para desbrozar su apunte crítico o su glosa ecfrástica en el inmenso libro de la naturaleza y donde pincel y pluma desatan su sinestésica simbiosis — ut pictura poesis, ut poesis pictura - al embozo de la adulterada expresión horaciana. ${ }^{4}$ Estos paréntesis o sabrosos intercolunios de naturaleza académica exceden a las convenciones del género y desplazan la jerarquía del discurso novelesco hacia su periferia, hacia el concierto de voces que peroran sobre las más peregrinas materias y donde la erudición sofoca a la narración bucólica. Este discurrir enciclopédico de los árcades lopescos devenidos en humanistas es una estrategia similar a la que transforma a los personajes cervantinos en los avezados lectores y críticos que, en el Quijote, abdican del relato caballeresco para apurar su competencia filológica. Inequívocamente, fueron estas divagaciones de los pastores humanistas las que contribuyeron al éxito editorial de La Arcadia pues en ellas se hallaba la sazón del relato.

Ha sido Lope poeta el que ha convocado más artículos y monografías sobre la autolectura a la que se somete el propio Fénix en sus composiciones líricas; Antonio Carreño (1990:1-2), que ilustró con minucia la oscilación del canon crítico al poético y viceversa en los versos no dramáticos de nuestro autor, advirtió que para describir los desplazamientos de la identidad lírica y autobiográfica de Lope

se debiera tener en cuenta: a) que Lope, ya cercano a su fin (ciclo de senectute), parodia su propia escritura (el “desengaño" es plural); b) que leyendo a los “otros” (a Góngora y a Quevedo, principalmente) afirma y niega a su vez (la aporía es clave) la 
propia voz; c) que atacando y suprimiendo públicamente a Góngora del canon de sus lecturas lo absorbe e imita; y, finalmente, d) que la función crítica (Discurso sobre la nueva poesía) afirma y niega la propia praxis poética. Lope, distinto en este sentido de Góngora y Quevedo, es el único poeta crítico de su época.

Estas esclarecedoras palabras delatan, in absentia, una tendencia abusiva y exhiben una lúcida apreciación de la trayectoria (meta)literaria del Fénix. Sánchez Jiménez (2015: 33) advirtió desde sus romances juveniles el procedimiento de la autocita en Lope, estrategia que se adensa en los ciclos finales de su producción. El exceso de biografismo que ha derrochado la crítica lopesca ha avalado con creces la ósmosis del autor con su obra, ya a través de la prosapia de heterónimos, ya a través del despiece de episodios vitales que conjuran sus prosas y versos ya merced a la migración (intertextual) de las composiciones que fluyen entre sus libros poéticos y sus comedias; este animadísimo teatro de contaminaciones nos avisa de la aguda conciencia que Lope tenía de su estatuto de escritor, de la recreación narcisista en su obra y de la omnisciencia con la que habitaba en su propia escritura con una suerte de deliberado "palimptexto", si se nos permite el neologismo. Más allá de las fronteras del disfraz autorial o de la auto-referencia, Lope de Vega atesora en su trayectoria un ejercicio de crítica textual como no hallamos en ningún otro y una constante visualización del oficio de escribir a la que contribuyó no poco la cualidad fanopeica de su arte al abrazo del parangón entre poesía y pintura que el Fénix desarrolló con hartas elocuencia y convicción. Y esta condición se decanta en la década de los años veinte cuando Lope enarbola la figura del pintor Juan van der Hamen como paradigma sinestésico del poeta claro dotado de natural ingenio, en parte con el objeto de ilustrar aspectos de la tarea del escritor en los que la pintura convergía, como la capacidad reproductiva, la reacción del receptor, las responsabilidades morales, el fin ideológico de la imitación o las capacidades técnicas del arte — según ha apuntado Sánchez Jiménez (2011: 275 y sigs.) -; se trata, por tanto, de especulaciones que no solo alcanzan al creador sino también al crítico que analiza en perspectiva la obra, de suerte tal que la representación del autor en su obra conlleva una reflexión sobre la percepción de la misma y esta actitud del lector y del espectador, extra e intra muros de la página y del lienzo, es ya cervantina.

Los poemas cultos de La Filomena irrumpen en la trayectoria del Fénix con transparente divergencia: su amalgama textual de sonetos, silvas, epístolas, novellas, églogas y prosas vienen avalados por un común espíritu libresco y por el anhelo del escritor de acreditarse en el horizonte de la "nueva poesía", que contesta y que imita. El gongorismo había perseguido a Lope, al menos, desde algún soneto de La Arcadia como el del pastor Olimpio articulado sobre el paradigma correlativo del cordobés (Lope de Vega, 1975:93):

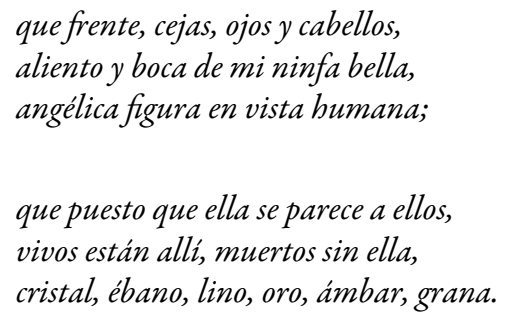

La imitación de la poética cultista además asomaba en los versos de la novela pastoril con el cultivo del esdrújulo emulando la estridencia rústica que Sannazaro perseguía; sin embargo, a Lope la imitación le llegaba del canario Bartolomé Cairasco de Figueroa, esdrujulista pertinaz cuyo Templo Militante, un descomunal flos sanctorum de música proparoxítona, andaba suelto en algunas canciones esdrújulas en la década de 1570 y que el propio Góngora imitó, como hizo notar José María Micó (2001:42-45). La moda despertó socarronas burlas e intencionados juicios con los que Cervantes o Lope de Vega retrataron sus alardes por "esdrujulizar el mundo". Los mismos que ironizaron sobre su fertilidad rítmica terminaron luego imitándolo hasta el punto de que la poética del verso esdrújulo hizo "escuela" o, al menos, irradió un conjunto significativo de seguidores que, en algún caso, recordaron los usos retóricos del "maestro": Cervantes, Lope de Vega o Góngora compusieron versos esdrújulos a modo del "canario cántico"; Juan de Arguijo, cuya academia a 
buen seguro visitó Cairasco - y también Lope en sus estancias en Sevilla一, flirteó con este tipo de verso; Antonio de Viana lo empleó en su Conquista de Tenerife - epopeya insular que fue saludada por Lope con un soneto laudatorio en los preliminares-; pasó el océano hasta la poesía de Sor Juana Inés de la Cruz y pervivió en el siglo xviii. Sin embargo, es de justicia advertir que, en el Siglo de Oro, el empleo del tempo dactílico se debió casi siempre a una intención paródica, burlesca y, cuanto menos, humorística o para pintar emociones excéntricas, deslizando un tono menor o de ludismo inocente que en nada corresponde a la intención de Cairasco. Su peculiaridad rítmica y fónica lo atrajeron, en alguna ocasión, al dominio de los vejámenes de academia, al regazo de aquellas reprensiones de punzante sátira y vuelo burlesco contra los poetas de certámenes. Cairasco no pudo evitar la percepción contaminada del verso esdrújulo hacia la atmósfera del concepto festivo y ligero, de suerte que los poetas de su tiempo lo administraron como una extravagancia fruto más del empeño voluntarioso que del hallazgo estético. Sin embargo, aquí radica, según Sánchez Robayna (1992), su contribución a la poética culta: en el intento de flexibilización de la lengua literaria por la vía del cultismo léxico, que impone un paisaje musical y conceptual nuevo. Desde Fernando de Herrera los deslizantes sdrucciolos determinaron una de las credenciales de la poética culta y Lope no se sustrae a ella cuando quiere afectar distinción y artificio con los esdrújulos consonantes de su Arcadia para los amantes desesperados o rechazados. A la pujanza del verso esdrújulo entre los poetas cultos volverá Lope en La Dorotea cuando Julio, Ludovico y César comentan con transparente mofa erudita la voz "Solitúdines", donde se ironiza no solo la poética del autor de las Soledades sino la absurda aplicación de los comentaristas en su estéril esfuerzo de desgranar la laberíntica jerga culterana: autor y lectores, versos y anotadores, poética y seguidores se ven sometidos a la inmisericorde parodia metaliteraria.

No es casual la elección del mito de Filomena para uno de los libros poéticos con los que el Fénix se postulaba como autor culto: la cruel y hermosa historia de la violación de la muchacha por su cuñado Tereo emplea la metáfora del bordado como texto cuando la muchacha, condenada al silencio, borda el infame estupro en un tapiz que hace llegar a su hermana Progne. La figura de la urdimbre como paradigma del texto es amplia y se sanciona con legitimidad etimológica como una variedad de la escritura; según cita Sánchez Robayna (1993:47), Roland Barthes ha advertido que

Texto procede de textus, participio pasivo de texo, que quiere decir tejer: el texto es un tejido de sentido enmarañados; pero asimismo, todo cuanto aparece como tejido puede leerse como un texto... lo bordado o tejido pertenece a la misma órbita metafórica de lo escrito.

Con el paradigma clásico de la "Égloga III" y el soneto v de Garcilaso ("Escrito está en mi alma vuestro gesto"), Lope ya había aludido al mito en La hermosura de Angélica y volverá a él en La Circe y en el Laurel de Apolo. Góngora también le dedica un exquisito soneto en 1584 (“Con diferencia tal, con gracia tanta"). El acto de tejer o bordar implica la razón de un universo (hombre, vida, naturaleza) tramado y ordenado en red mediante una continua e imparable devanadera (como en "Las Hilanderas" o Parcas velazqueñas) o una aguja como en el mito. El texto es, a su vez, escritura de signos en maraña, sistema de letras en urdimbre. En ambos subyace el mismo objetivo de representación (la historia en el tapiz) conceptualizado en la metáfora de la escritura: el tejido puede leerse (y escribirse o pintarse) como texto y el texto puede entenderse como tejido.

El talante libresco de La Filomena se prolonga en el "Discurso de la nueva poesía", donde el Fénix engola el tono de su discurso con el concurso de abundantes citas y autoridades para ejercitarse de crítico glosando y anotando modelos literarios que refrenaran el avasallador gongorismo, ya consolidado tras las Soledades y el Polifemo. El ensayo es paradigma de la ambigüedad con la que Lope se condujo siempre frente a la poesía cultista: bajo los reproches al nuevo estilo se decanta la admiración y el reconocimiento de la excelencia lírica del cordobés. En La Filomena además aprovecha la ocasión para hacer summa literaria propia —a las que Lope era dado- aludiendo a su producción desde La Arcadia al Triunfo de la fe en los reinos del Japón sin perder pie para referir el caudal de sus comedias ("novecientas fábulas oídas/ por toda España") con alguna autocita de La Arcadia ("La verde primavera/ de mis floridos años/ pasé cautivo, Amor, en tus prisiones"). 
Esta progresiva suspensión de la materia lírica o narrativa en aras de una posición filológica frente a sí y a los otros contamina también el signo de La Circe y establece una estrategia de endogamia intertextual cuando incluye, en la segunda, el comento del último soneto de la primera, el citadísimo "La calidad elementar resiste", en la Epístola ix dirigida a don Francisco López de Aguilar. Los alcances platónicos de la composición y la pretensión cultista de sus conceptos no esconden el subterfugio de tratarse y concederse a sí mismo el estatuto de autoridad clásica, glosada verso a verso, en parangón del ejército de comentaristas y anotadores que hacían lo propio con Góngora, amén de que el Canto II de La Circe, en que se tratan los amores de Polifemo, Acis y Galatea, respira gongorismo en una suerte de deliberada palimptextualidad bajo el semejante molde de la octava real y en analogía plástica y retórica con su cercano paradigma.

Marco Presotto arguye que Lope quiso distanciarse de Cervantes al publicar sus cuatro novellas bajo el amparo de dos libros misceláneos (2007:11). Los relatos lopescos no anuncian ejemplaridad y se contienen en selvas literarias destinadas a lectores cultos. Esta premisa determina la instrumentalización de las Novelas a Marcia Leonarda como un medio para reflexionar sobre la creación narrativa en sí, para elaborar una teoría literaria de un género que carecía de ella (Scordilis Brownlee, 1981) o para deslizar su parecer, disfrazado en la voz del narrador o de los personajes, acerca de la literatura coetánea. Ocurre aquí que ni narrador ni narrataria son convencionales toda vez que, en el juego de la seducción entre ambos, ella parece determinar el tema, los personajes y sus peripecias, así como propiciar las digresiones, interviniendo como un narrador causativo, en aparente régimen de co-autoría, plenamente visible a lo largo de las novellas. Y lo mismo valdrá para el narrador, cuya presencia real y tangible en la obra destila un yo que se repite y que conversa con Marcia. Ambos imantarán la atención del lector privando de luz cenital a los personajes de la ficción "novellesca". La comparecencia y complicidad de un narratario entrometido a cuya medida han de conformarse los relatos no es una novedad. En los cuentos tradicionales se exige la participación de quien escucha: conocidísimo es el ejemplo del cuento que Sancho le narra a don Quijote para distraerlo y en el que le reclama su atención, ya que más adelante convocará su participación (Quijote I, 20). Las Novelas de Lope no se diferencian en este aspecto de los cuentos populares, pues bajo el embozo de la oralidad (y de la epistolaridad [FernándezCifuentes, 2013:13-27]) también Marcia, como don Quijote, se verá apercibida por el narrador para recordar aspectos del relato: "No se olvide, pues, vuestra merced de Zulema (...) que me importa para adelante que le tenga en la memoria" (Lope de Vega, 2002: 260-1); o para emitir juicios sobre lo acontecido: "Vuestra merced juzgue si esta dama era cuerda, que yo nunca me he puesto a corregir a quien ama” (247). Lope tomará de Boccaccio la capacidad enjuiciadora de los narradores-narratarios y la multiplicidad especular de la narración al albergar mini-relatos en las digresiones. Y para avivar el diálogo, cubiertas adentro, de autor y lectora el Fénix emplea los “intercolunios" con profusión en sus Novelas para deleite —o desesperación, que la señora Marcia seguramente preferiría la continuación de la historia antes que conocer los principios de la retórica - de su narrataria. Estos desvíos - o desvaríos - de la historia principal permiten introducir un escrutinio filológico sobre una gran variedad de temas, de los que, sin duda, los más llamativos son aquellos que se ocupan de literatura, aquellos en los que aparece la reflexión literaria dentro de la obra. A propósito de la verosimilitud el narrador se dirige al lector para discutir sobre la novela que lee; así, en La desdich a por la honra se apostilla el celo minucioso de quien cuenta: "y dándole los brazos y una cadena, de las que llaman 'banda', de peso de ciento y cincuenta escudos (que soy tan puntual novelador, que aun he querido que no le quede a vuestra merced este escrúpulo de lo que pasaba) le dijo que le contase todo el suceso" (Lope de Vega, 2002: 196), pues - a juicio de Carreño:

es técnica cervantina el que el narrador comente, a modo de crítica y observación irónica, sobre el proceso de narrar, teniendo en cuenta a un lector que sigue la narración como personaje de ella. Se funde así la doble función de narrador y autor; de personaje y lector; de novela y metanovela. (Lope de Vega, 2002: 196, 59n.)

La figura del narrador autoconsciente funciona en Lope con un distanciamiento de los hechos ficticios, en los que no participa, pero le confía a Marcia su intención de superar a Cervantes con sus narraciones breves 
o que novellar no es negocio diferente de escribir comedias. El Fénix es, asimismo, el primer lector de las mismas cuya interpretación comenta en una ceremonia de forzada plática con una interlocutora que le sirve para ponerse, ante todo, a prueba a sí mismo como novelador — según Díaz-Migoyo (1982). Este onanista escrilector que se exhibe ante su narrataria y ante lectores cultos e iletrados, que para todos hay aparejo, sazona sus digresiones para enamorar o hacer enfadar a Marta, para ejercer de mentor en la lectura o para instruirla, para ilustrar usos en boga de la vida cotidiana (como tomar el acero o la altura conveniente que deben poseer los chapines), para aderezar el relato con anécdotas, cuentos y mitos y para adentrarse en la naturaleza misma del contar y del leer.

Lope hiló fino en las digresiones sobre literatura: ha sido especialmente comentado el largo "intercolunio" sobre el final de La prudente venganza acerca de la licitud o no de la reparación sangrienta del honor a manos del agraviado: el Fénix pondera la solución cristiana del perdón debido simplemente al contexto de recepción de la novella (la intimidad individual de su lectura), fórmula que no admitiría la representación teatral. Aduce, asimismo, citas de La Celestina o del Amadis para justificar las leyes de la narración tamizadas por la burla y la ironía, como la digresión referida al idealismo pertinaz de las novelas pastoriles: "Ya se llegaba la hora del comer y ponían las mesas - para que sepa vuestra merced que no es esta novela libro de pastores, sino que han de comer y cenar todas las veces que se ofreciere ocasión" (Lope de Vega, 2002:241) o la sátira del empleo de las figuras retóricas. Sin embargo, no todo es mofa zumbona en el discurso de estos apartes del relato, pues acude al concurso de las referencias literarias para instruir a la interlocutora con un tono pedagógico, como las alusiones a la novela bizantina o a las convenciones del teatro y las diferencias verticales que se han de advertir entre señores y criados o las encomiendas que se han de observar para el decoro. Al hilo de la propiedad lingüística Lope inserta divagaciones sobre el idioma y su progresiva adulteración por efecto de la tradición culterana; no pierde baza el Fénix para blandir estoques contra el gongorismo extranjerizante:

Esta voz [afratelaban], señora Marcia, es italiana; no se altere vuestra merced, que ya hay quien diga que están bien en nuestra lengua cuantas peregrinidades tiene el universo, de suerte que aunque venga huyendo una oración bárbara de la griega, latina, francesa o garamanta, se puede acoger a nuestra idioma, que se ha hecho casa de embajador, valiéndose de que no se ha de hablar común, porque es vulgar bajeza. (Lope de Vega, 2002:294)

La obsesión de nuestro autor por la poética cultista menudea en muchas digresiones de las novellas, sin conceder tregua hasta sus últimas obras: la crítica de los poetas cultos es un lugar común del Lope metaliterario. En el Laurel de Apolo con otras rimas de 1630 compone la que tal vez sea una de las más ingeniosas diatribas contra el nuevo credo estético (Lope de Vega, 1988: 262):

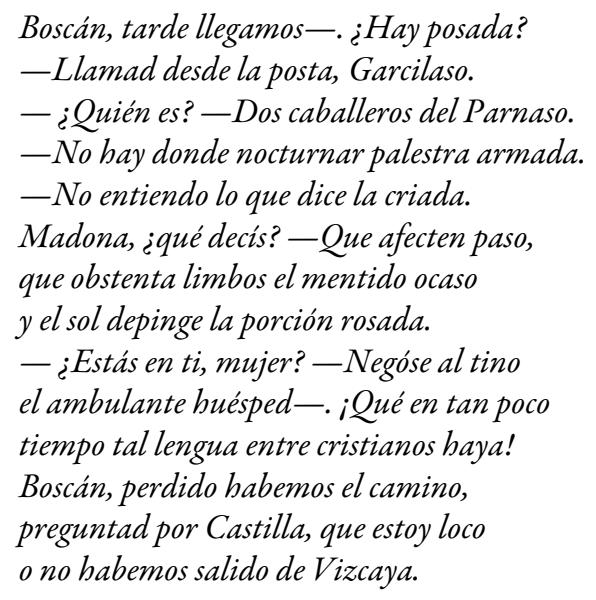

El sabor metapoético de la composición, una admirable parodia en clave filológica, esgrime una secuencia teatral entre la lega huéspeda con su parla culterana y los dos poetas renacentistas, confusos y extrañados ante la insólita jerga, que identifican con la fonética incomprensible del vascuence. El remate crítico contra 
el gongorismo hallará mejor acomodo en las prosas de La Dorotea y el conciliábulo de eruditos que hace la autopsia del soneto, al gongorino modo, inmisericordemente burlesco e infectado de voces y giros cultistas que incluyen, en sentencia condenatoria, el dictamen del lector: "Estos versos, ¿̇son turcos o tudescos?/ Tú, letor Garibay, si eres bamburrio,/ apláudelos, que son cultidiablescos” (Lope de Vega, 1996:345).

En las Novelas a Marcia Leonarda el autor comparece en el relato por propia iniciativa, citándose, en boca de los personajes que refieren la lectura de alguna de sus obras o mediante la inserción de hechos autobiográficos más allá del galanteo con su interlocutora, como la decisión de imprimir sus comedias bajo Partes o sus lejanos amores con Elena Osorio. Es ahí, en la aparición de Lope de Vega como él mismo dentro de sus obras donde reside la genialidad tanto de las Novelas como de La Dorotea. Sus propios personajes, como los del Quijote, existen en un mundo compartido con su autor y con sus obras. Lope de Vega se convierte en un compareciente más del relato y las fronteras de la ficción se diluyen en una dimensión ucrónica donde el escritor se ficcionaliza y los personajes cobran estatuto de realidad: no hay nada más cervantino.

Las Novelas se conciben como un juego metaficcional a varios niveles: en primer lugar, debido al carácter lúdico en torno a la creación de los relatos mismos; en segundo lugar, por el diálogo y por el comentario de la narración que se establece entre quien cuenta y quien lee, interlocutora que, además, induce la escritura; en tercer lugar, porque la identidad de la narrataria contamina los objetivos del autor y el contar es una excusa para seducir y para exhibir su ejercicio de novelista y, esencialmente en cuarto lugar, porque el valor tradicional de la narración se transforma, pues la atención pasa de los personajes a los agentes narrativos narrador y narrataria—, al modo del Lazarillo entre el pícaro y ese intrigante y curioso "Vuestra Merced" que “escribe se le escriba y relate el caso muy por extenso". Aquí, el viejo amante empleará sus artes de galanteo con la bella dama de ojos verdes merced a la asistencia de impertinentes digresiones que agudizan la confusión autorial, acogen un nuevo arte de novellar y desplazan las anécdotas convencionales de la ficción narrativa a una "deliciosa maraña de menudencias" - al decir de Francisco Rico- brindadas como foro crítico de un escrilector que se comenta en un discurso paralelo de vocación metaliteraria de clara filiación cervantina y de prolepsis unamuniana (novelas acerca de cómo se hacen las novelas).

Y atracamos en el último puerto de nuestro periplo: con La Dorotea se radicalizan los empleos metaescriturarios en una obra cuya hibridez rezuma el espíritu de summa, confesión, juego, dominio, silva miscelánea, antología y centón de la literatura de la literatura donde se abandona la "acción en prosa" para ocuparse de las estrategias de la compositio (Brito Díaz, 2003 y 2009). Y esta desviación anestesia su naturaleza dramática aunque lo metaficcional esté formulado teatralmente con una impostura que impregna la visión externa del discurso de la anotación contenido en la trama y, a veces, indiferenciado de ella. La Dorotea acusa la aguda literaturización libresca de los personajes que observamos en el Quijote por el diálogo erudito y digresivo que asalta a cada paso. Y esto deviene en una disidencia de los individuos de la acción como seres de ficcióntoda vez que el metalenguaje, la impertinente tendencia de objetivar y analizar el discurso, privilegia la transformación de la palabra - vivida, sentida y formulada en la acción en prosa por los individuos que la habitan - en letra glosada, discutida y desmembrada en un comento, un debate, una apostilla crítica, un lugar erudito o una pesquisa filológica, que se actualiza desde el almacén de la memoria y del conocimiento.

La Dorotea traza así un itinerario donde la acción está intervenida por la erudición que engendra, de modo tal que los personajes viven para leer, perorar o comentar con fruición filológica en forma de glosa la escritura que se despliega ante ellos y que gestionan con pose libresca congestionados por la saturación de lo literario. Aquí residen todos los Lopes que hay en el Fénix: el que apura en sus ficciones los disfraces de su vida, el que analiza en escrutinio irónico la literatura ajena y propia, el que afecta erudición y se acredita como innovador, el que desliza textos propios y ajenos y transforma en ficción la recepción de los mismos, el que homenajea y parodia todos los géneros (de ahí el molde de la comedia erudita de sabor celestinesco donde son amparados la narración, la poesía y el teatro), el que afianza la actitud exegética (ajena en el Laurel de Apolo; propia en la "Égloga a Claudio"), el que suspende el principio de la ficción para intervenirla con un discurso exterior tan cercano al distanciamiento brechtiano con el que Cervantes se impone en el Quijote. El cervantismo del 
Fénix es de "segundo grado": falta en los personajes lopescos la propia anagnórisis como criaturas de ficción y un mayor ahondamiento especulativo sobre las peripecias de la teoría de la invención literaria. La Dorotea se abre paso en la trayectoria de nuestro autor como la maniera consolidada de la palabra referencial de la literatura en cornucópico inventario en el que lo libresco sostiene el propio discurso irónico de la ficción. Aquí también los personajes escriviven en el pie de la letray su existir como seres literarios viene avalado por su conciencia del bullir de la grafía escrita, por su identidad filológica. Se ha consumado el ciclo de la literatura: cuando en La Dorotea Teodora increpa a su hija ("¿Lloras? Bien haces; pero no pienses enternecerme; que no hago yo aquí papel de galán celoso, sino de madre honrada" [Lope de Vega, 1996: 112]) el personaje ha transferido su identidad más allá de la ficción y su definición ontológica se acredita por su pulsión bibliófila. Teodora se retrata y nos retrata a todos nosotros como lectores insaciables del infinito libro del mundo que soñaron Don Juan Manuel, Mallarmé o Borges.

\section{BiBLIOGRAFÍA CITADA}

Brito Díaz, Carlos, 1996. Lope y el mundo escrito. Variantes estéticas y epistemológicas del libro como símbolo en las poesias y prosas de Lope de Vega, La Laguna: Universidad.

Brito Díaz, Carlos, 1998. "Oficina y museo de la letra: dicho y deposición para las artes de la escritura en La Arcadia”, Anuario Lope de Vega, iv, 55-64.

Brito Díaz, Carlos, 2003. "Lope en Lope: los palimpsestos del Fénix en su propia escritura (La Dorotea)", La Perinola. Revista de investigación quevediana, 7, 103-121.

Brito Díaz, Carlos, 2009. “Burlas y veras de Lope: La Dorotea como escrutinio”, Anuario Lope de Vega, xv, 11-18.

Brito Díaz, Carlos, 2010. “'Campos de aljófar siembras de granates': a propósito del elogio paradójico en Lope de Vega”, eHumanista.Journal of Iberian Studies, 15, 251-261.

Calvo Serraller, Francisco, 1991. Teoría de la pintura del Siglo de Oro, Madrid: Cátedra.

Carreño, Antonio, 1990. "Lope de Vega: del canon crítico al poético", Ínsula, 520, 1-2.

Castells Molina, Isabel, 2000. Cervantes y la novela española contemporánea, La Laguna: Universidad.

Cervantes Saavedra, Miguel de, 1980. Viaje del Parnaso, ed. facsimilar [Madrid: viuda de Alonso Martín, 1614], Madrid: José Esteban editor.

Cervantes Saavedra, Miguel de, 1996. Don Quijote de la Mancha, ed. revisada, introducción y notas de M. de Riquer, Barcelona: Planeta.

Curtius, Ernest Robert, 1984. “El libro como simbolo”, Literatura europea y Edad Media latina, M. Frenk Alatorre y A. Alatorre (trad.), Madrid: Fondo de Cultura Económica, vol. I, 423-489.

Díaz-Migoyo, Gonzalo, 1982. "Escrilectura amorosa de la novela (Las Novelas a Marcia Leonarda de Lope de Vega)", Quimera, vii-viii, 21-22, 54-56.

Egido, Aurora, 1995. “Escritura y poesía. Lope al pie de la letra”, Edad de Oro, xiv, 121-149.

Fernández-Cifuentes, María Ángeles, 2013. “'Mandóme vuestra merced escribir una novela': epistolaridad en las Novelas a Marcia Leonarda", Tradición e innovación en las "Novelas a Marcia Leonarda" de Lope de Vega, New York: Peter Lang, 13-27.

García Berrio, Antonio y Teresa Hernández Fernández, 1988. "Ut pictura poesis: actualización poética de la teoría humanística de las artes plásticas”, Ut poesis pictura. Poética del arte visual, Madrid: Tecnos.

Micó Juan, José María, 2001. “Cairasco de Figueroa, 'maestro’ de Góngora”, De Góngora, Madrid: Biblioteca Nueva, $42-45$.

Mosquera De Figueroa, Cristóbal, 2010. Paradojas. Paradoja en loor de una nariz muy grande. Paradoja en loor de las bubas, edición y estudio de V. Núñez Rivera, Salamanca: Universidad. 
Núñez Rivera, Valentín, 1997. “Tradición retórica y erotismo en los 'Paradoxa Enkomia' de Hurtado de Mendoza”, El sexo en la literatura, L. Gómez Canseco, P. L. Zambrano Carballo y L, Alonso Gallo (coords.), Huelva: Universidad, 99-122.

Núñez Rivera, Valentín, 1998. "Para la trayectoria del encomio paradójico en la literatura española del Siglo de Oro. El caso de Mosquera de Figueroa", en: M. ${ }^{a}$ C. García de Enterría y A. Cordón Mesa (eds.), Actas del iv Congreso Internacional de la Asociación Internacional Siglo de Oro (AISO), Universidad de Alcalá de Henares: Servicio de Publicaciones, tomo II, 1133-1143.

Portús Pérez, Javier, 1999. Pintura y pensamiento en la España de Lope de Vega, Hondarribia: Nerea.

Presotto, Marco, 2007. "Introducción” a Lope de Vega, Novelas a Marcia Leonarda, Madrid: Castalia.

Sánchez Jiménez, Antonio, 2007. “Introducción” a Lope de Vega, La Dragontea, Madrid: Cátedra, 13-113.

Sánchez Jiménez, Antonio, 2011. El pincel y el Fénix. Pintura y literatura en la obra de Lope de Vega Carpio, Madrid/ Frankfurt: Iberoamericana/Vervuert.

Sánchez Jiménez, Antonio, 2015. “Introducción” a Lope de Vega, Romances de juventud, Madrid: Cátedra, 11-156.

Sánchez Robayna, Andrés, 1992. Estudios sobre Cairasco de Figueroa, La Laguna: Real Sociedad Económica de Amigos del País de Tenerife.

Sánchez Robayna, Andrés, 1993. "Góngora y el texto del mundo”, Silva gongorina, Madrid: Cátedra, 43-56.

Scordilis Brownlee, Marina, 1981. The Poetics of Literary Theory. Lope de Vega's "Novelas a Marcia Leonarda" and their Cervantine Context, Madrid: Porrúa Turanzas.

Sebastián, Santiago, 1995. “Las Meninas': un retrato pedagógico con trasfondo político”, Emblemática e historia del arte, Madrid: Cátedra, 232-249.

Vega Carpio, Lope de, 1975. La Arcadia, ed. Edwin S. Morby, Madrid: Castalia.

Vega Carpio, Lope de, 1988. Lírica, José Manuel Blecua (ed.), Madrid: Castalia.

Vega Carpio, Lope de, 1996. La Dorotea, José Manuel Blecua (ed.), Madrid: Cátedra.

Vega Carpio, Lope de, 2002. Novelas a Marcia Leonarda, Antonio Carreño (ed.), Madrid: Cátedra.

Vega Carpio, Lope de, 2008. Rimas humanas y divinas del licenciado Tomé de Burguillos, M. Cuiñ

\section{Notas}

1 Cervantes recoge este lugar común en el soneto preliminar ("Pues veis que no me han dado algún soneto,/ que ilustre deste libro la portada,/ venid vos, pluma mía mal cortada,/ y hacedle, aunque carezca de discreto”) del Viaje del Parnaso (1980: viii) y en las célebres palabras finales del Quijote (II, 74), que celebran la conjunción del autor con su péñola (1996: 1098): "Para mí sola nació don Quijote, y yo para él; él supo obrar y yo escribir; solos los dos somos para en uno". Es obvia la intención burlesca de Lope con esta licencia retórica.

2 El cuidadísimo capítulo que Curtius (1984, I: 423-489) dedica a la metafórica del libro y de la escritura es el punto de partida para nuestro análisis del libro como símbolo en la obra no dramática del Fénix (1996).

3 Sobre los audaces empleos cervantinos en la narrativa actual mediante la aplicación de una rica metatextualidad, véase el panorama crítico de I. Castells Molina (2000) y la rica bibliografía allí contenida.

4 Véase el capítulo I del trabajo de inexcusable referencia de García Berrio y Hernández Fernández (1988: 11-34). 